\title{
Prey-Predator Interactions of Pacific Cod Gadus macrocephalus and Water Temperature
}

\author{
Kohei Kihara*1 and Allen M. Shimada*2 \\ (Received June 24, 1988)
}

\begin{abstract}
The influence of bottom water temperature upon the dynamics of trophic relationships between prey and predator of Pacific cod was examined in the eastern Bering Sea during summers from 1979 to 1984. Pacific cod was partitioned into categories by sex and fork length. The common occurrence between small Pacific cod (male \& female $<30 \mathrm{~cm}$ in fork length) and walleye pollock (male $\&$ female $>51 \mathrm{~cm}$ ) was found to vary significantly with bottom temperature. Area overlaps between large Pacific cod and small walleye pollock (female $<20 \mathrm{~cm}$ ), searcher, pink shrimp, rock sole, and wattled eelpout which are prey of Pacific cod were also found to have significant correlations with ambient temperature. This study has suggested that bottom water temperature promotes concurrence of species which accelerates and changes predation and competition between predator and prey populations of Pacific cod.
\end{abstract}

Trophic interactions between predator, prey, and competitor are an important biological process that is influenced by local community structure. Recent studies into the structure of demersal communities in the eastern Bering Sea have emphasized temporal changes in species composition and spatial distribution. These alterations have been linked to variation in the marine environment, mainly through fluctuations in water temperature and salinity. ${ }^{1-3)}$

While species coexistence, in the form of spatial and temporal overlap, helps determine ecosystem; such concurrence may also be affected by the abiotic environment. The previous paper ${ }^{4}$ examined this hypothesis by studying the effect of water temperature on predator-prey interactions of walleye pollock Theragra chalcogramma. This paper extends the study on trophic relationships of Pacific cod Gadus macrocephalus, another principal groundfish species in the region.

\section{Materials and Methods}

Groundfish catch data were obtained from annual research trawl surveys conducted by the
Northwest and Alaska Fisheries Center (NWAFC) between May and August from 1979 to 1984. Bottom tows of 30 -minutes duration were completed at stations spaced 20 nautical mile apart over the eastern shelf (Fig. 1). The numbers of successful trawl stations included in the analysis were 317 (1979), 311 (1980), 280 (1981), 314 (1982), and 324 (1984), respectively. The sampling protocol and characteristics of the vesseles and trawl gears employed on these surveys can be found in data reports issued by the NWAFC. ${ }^{\text {s) }}$ Water temperature on bottom was obtained by expendable bathythermograph (XBT) at each station.

Classification of major predators and prey of Pacific cod was based on a review of the literatures.*3,*4,8-8) Major predators of Pacific cod considered in this study: Pacific halibut Hippoglossus stenolepis ( $>31 \mathrm{~cm}$ in fork length), Pacific cod Gadus macrocephalus (male \& female $>61 \mathrm{~cm}$ in fork length), walleye pollock Theragra chalcogramma (male \& female $>51 \mathrm{~cm}$ ), Yellow Irish lord Hemilepidotus jordani, Bigmouth sculpin Hemitripterus bolini, Thorny sculpin Icelus spiniger, Greenland turbot Reinhardtius hippoglossoides, and Arrowtooth flounder Atheresthes

*1 Tokyo University of Fisheries, Konan, Minato, Tokyo 108, Japan (木原興平: 東京水産大学).

*2 Northwest and Alaska Fisheries Center, NOAA, Sand Point Way N. E., Seattle, Washington 98115 , U.S.A. (アレン·M・シマダ: 米国・北西・アラスカ水産センター).

*3 K. Mito: Food relationships among benthic fish populations in the Bering Sea: on the Theragra chalcogramma fishing grounds in October and November of 1972, Master Thesis, Hokkaido Univ., Japan, $135 \mathrm{p}$ (1974).

*4 M. S. Yang: Food habits and daily ration of Greenland halibut Reinhardtius hippoglossoides in the eastern Bering Sea, Master Thesis, Univ. Washington, Washington, 1987, 57 p. 


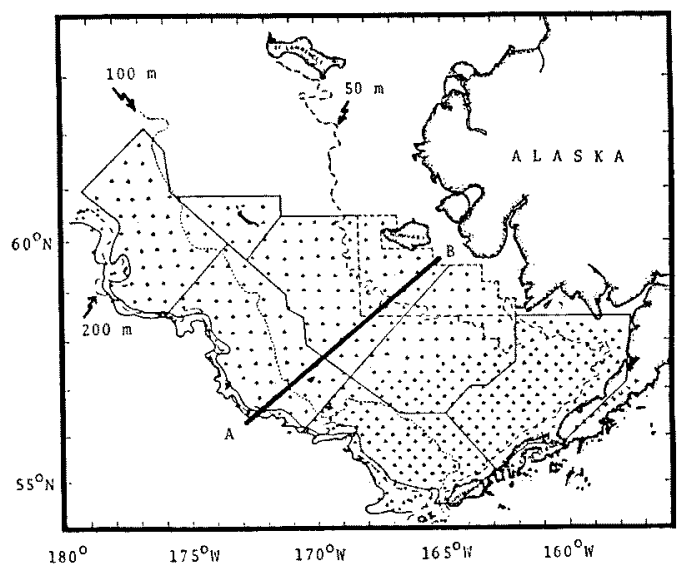

Fig. 1. Survey area and fixed trawl sampling stations occupied each summer from 1979 to 1984 . AB line divides the northwest and the southeast regions of the shelf.

stomias. Prey of Pacific cod included walleye pollock (male \& female $<50 \mathrm{~cm}$ ), Pacific cod (male \& female $<60 \mathrm{~cm}$ ), Capelin Mallotus villosus, Shortfin ellpout Lycodes brevipes, wattled eelpout Lycodes palearis, flathead sole Hippoglossoides elassodon, rock sole Lepidopsetta bilineata, Pacific sandfish Trichodon trichodon, searcher Bathymaster signatus, and pink shrimp Pandalus borealis.

An affinity of index based on recurrent group analysis was calculated to determine the degree of co-occurrence by E. W. Fager's method. $\left.{ }^{10}, 11\right)$ This index is expressed by the geometric mean of the proportion of joint occurrence, corrected for sample size: $c / \sqrt{a b}-1 / 2 \sqrt{b}$, where $c$ is the numbers of joint occurrence; $a$ and $b$ are the total number of occurrences of species A and B respectively. Species are assigned to each letter such that $a \leq b$. As this analysis is made on the basis of presence or absence of the species in each trawl sample, their abundances are neglected in the analyses. This study defined the number of occurrences of each species as the number of stations where it represents a recorded catch weight $\geq 45 \mathrm{~g}$. This is the minimum value carried in the NWAFC computer data base. The affinity indices were calculated for all possible combinations of species having known trophic interactions with Pacific cod.

This study considered bottom water temperature as one readily obtained parameter of the abiotic marine environment. Mean bottom water temperatures were calculated for the overall, northwest and southeast regions of the eastern Bering Sea. These regions were separated by the AB line shown in Fig. 1.

\section{Results and Discussion}

\section{Bottom Water Temperature}

Mean bottom water temperatures were found to change over a two year cycle, declining between 1979 and 1984 (Fig. 2). Northwest continental shelf temperature was $1-2^{\circ} \mathrm{C}$ colder than southeast temperatures. This trend reversed in 1982 southeast water was colder. Annual variation in bottom temperature was usually more pronounced over the southeast shelf than in the northwest region. ${ }^{3,4)}$

\section{Influence of Water Temperature on Prey-Predator Interactions}

In this study correlation coefficients were calculated between affinity indices of species pairs having high affinity and mean bottom temperature to elucidate the effect of temperature on the stability of known predator-prey relationships. Although affinity indices of each species pair were described in the previous paper, ${ }^{3)}$ range of the index was 0-0.89. Significant correlations for Pacific cod interactions and mean bottom water

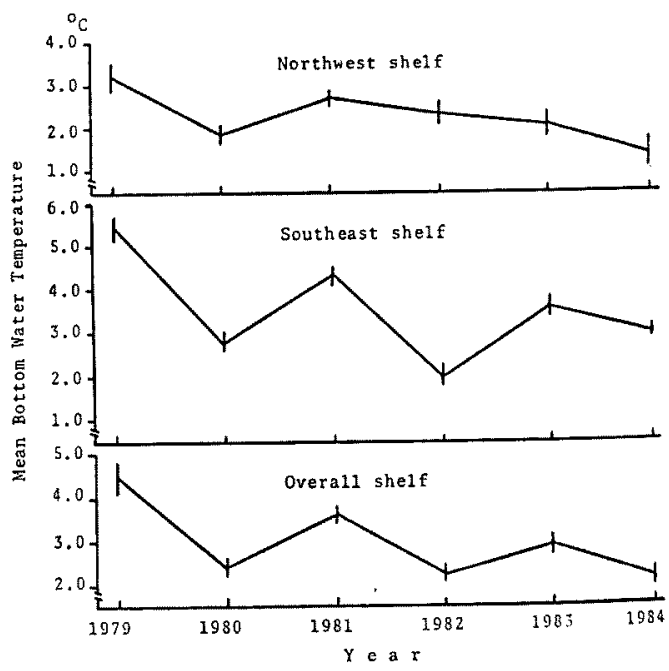

Fig. 2. Fluctuations of mean bottom water temperatures of overall, northwest, and southeast shelf regions of the eastern Bering Sea during summers from 1979 to 1984. Regions are divided by $A B$ line in Fig. 1. Vertical lines indicate $95 \%$ confidence intervals of the mean water temperatures. 


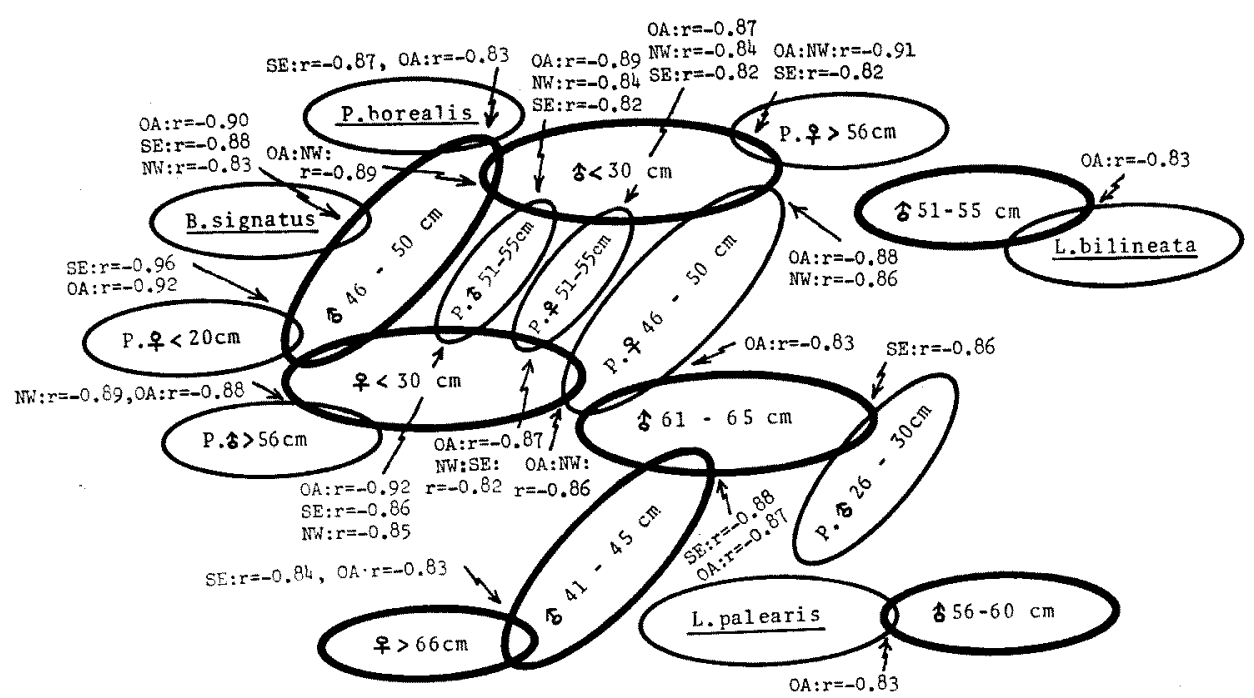

Fig. 3. Major relationships between mutual occurrences of major Pacific cod prey-predator and Pacific cod of different sex and size, and mean bottom water temperatures (OA: overall shelf, NW: northwest shelf, SE: southeast shelf) of the eastern Bering Sea during summers from 1979 to 1984. Ellipses represent habitats of predator and prey, and Pacific cod groups by sex and size. ?: unknown sex. P.: walleye pollock. Significance level $(p)$ of correlation coefficient $r=0.81, p=0.05 ; r=0.88, p=0.02 ; r=0.92, p=0.01$.

temperature are given in Fig. 3.

The affinities of three prey categories (female walleye pollock smaller than $20 \mathrm{~cm}$, pink shrimp, and searcher) with Pacific cod (male $46-50 \mathrm{~cm}$ ) had a significant negative relationship with bottom temperature. Wattled eelpout and rock sole also changed their prey relationship with Pacific cod (male $51-55 \mathrm{~cm}, 56-60 \mathrm{~cm}$ ) according to a negative correlation with water temperature (Fig. 3). Therefore at low water temperature the potential for spatial overlap of Pacific cod and these prey is enhanced.

Pacific cod (male $<30 \mathrm{~cm}$ ) and large walleye pollock (female $>56 \mathrm{~cm}$ ) were consistently paired through the six years examined. The affinity index of this pair was significantly correlated with bottom temperature (northwest shelf and overall shelf: $r=-0.91, p<0.02$, southeast shelf: $r=$ $-0.82, p<0.05$ ). Pacific cod (female $<30 \mathrm{~cm}$ ) and large walleye pollock (male $>56 \mathrm{~cm}$ ) were also strongly paired, and the variation of their affinity index was significantly tied to changes in bottom temperature (overall shelf: $r=-0.88$, $p<0.02$, northwest shelf : $r=-0.89, p<0.02$ ). As habitat of this walleye pollock (male $>56 \mathrm{~cm}$ ) changed with the northwest bottom temperature (correlation coefficient $r=-0.84, p<0.05$ ), it is considered that their distribution extends in breadth. Accordingly, co-occurrence between large walleye pollock and small Pacific cod is found of a greater degree in colder years. This suggests that bottom temperature affects the likelihood of walleye pollock predation on small Pacific cod.

The inhabited area of smaller walleye pollock (male $26-30 \mathrm{~cm}$ ) changed according to the variation of bottom water temperature on the northwest shelf $(r=0.81, p<0.05)$. Coexistence between this prey category and large Pacific cod (male $61-65 \mathrm{~cm}$ ) correlated negatively with bottom temperature (southeast shelf: $r=-0.86, p<0.05$, overall shelf: $r=-0.81, p<0.05$ ). Although the distribution of smaller walleye pollock will expand over the northwest shelf during warm-water years, there is an accompanying reduction of its common habitat with large Pacific cod. To some degree, the vulnerability of small pollock to cod predation would be diminished.

The habitat of smaller walleye pollock (male $31-35 \mathrm{~cm}$ ) was closely related to the variation of mean bottom water temperature on the northwest shelf $(r=0.92, p<0.01)$. This prey category had high affinity with large Pacific cod (female $>66 \mathrm{~cm}$ ), but there was no observed relation between the index and bottom temperature. As water temperature changes, the distribution of walleye pollock also shifted, but the area of their common distribution was not correlated with this 
shift. Although the inhabited area varies dependently with water temperature, these species pairs coexist due to factors other than water temperature.

Small Pacific cod (male and female $<30 \mathrm{~cm}$ ) and walleye pollock (female $46-50 \mathrm{~cm}$, male and female $51-55 \mathrm{~cm}$ ) correlated significantly with bottom temperature (Fig. 3). With lower bottom water temperature, the potential of predation on the small Pacific cod by large adult pollock is increased.

This study also identified many predator-prey pairs with high affinity, and with no significant correlation to bottom water temperature. These included following pairs: Pacific cod (male 31-35, $41-45 \mathrm{~cm}) /$ Pacific cod (female $<55 \mathrm{~cm}$ ), Pacific cod (female $>66 \mathrm{~cm}$ ) $/$ walleye pollock (male 31 $40 \mathrm{~cm}$ ), Pacific cod (male $<30 \mathrm{~cm}$ ) $/$ Pacific cod (male $31-40 \mathrm{~cm}$ ), and walleye pollock (male and female $>56 \mathrm{~cm}$ ) $/$ Pacific cod (male and female $<50 \mathrm{~cm}$ ). These observations suggest that cannibalism in Pacific cod can occur without any significant influence of water temperature. Flathead sole and its predator Pacific cod (male and female $>66 \mathrm{~cm}$ ) had high affinity index through 6 years without significant correlations to bottom water temperature. Factors other than bottom temperature are thought to influence the rate of these interactions.

Multispecies food habit studies have been proceeded along several approaches. Mito (1974) examined taxonomically diverse species on the outer shelf of the eastern Bering Sea and found feeding differences leading to ecological segregation between species.*1 Among morphologically similar species, spatial segregation by depth was found to account for the observed separation in diet.*2 Although other papers have studied predatorprey relationships of demersal fish, most have not examined the influence of the abiotic environment upon the trophic interactions of species. $* 1, * 2,7-\vartheta)$ Studies into the influence of ambient water temperature on the coexistence of key prey and predator relationships will further enhance our understanding of trophic interactions in the eastern Bering Sea.

\section{Acknowledgment}

The assistance of Prof. Dr. W. S. Wooster, University of Washington, is greatfully acknowledged.

\section{References}

1) K. Kihara: Nippon Suisan Gakkaishi, 49, 41-47 (1983).

2) K. Kihara: Nippon Suisan Gakkaishi, 49, 49-54 (1983).

3) K. Kihara and A. M. Shimada: Bull. Int. North Pacific Fish. Comm., 47, 31-48 (1986).

4) K. Kihara and A. M. Shimada: Nippon Suisan Gakkaishi, 54, 1131-1135 (1988).

5) R. G. Bakkala, J. J. Traynor, K. Teshima, A. M. Shimada, and H. Yamaguchi: U.S. Dep. Commer., NOAA Tech. Memo. NMFS F/NWC87,448 p. (1985).

6) A. M. Shimada, P. A. Livingston, and J. June: Fish. Bull., (in review)

7) K. Wakabayashi: Bull. Int. Pacific Fish. Comm., 47, 3-30 (1986).

8) P. A. Livingston, D. A. Dwyer, D. L. Wencker, M. S. Yang, and G. M. Lang: Bull. Int. North Pacific Fish. Conm., 47, 49-65 (1986).

9) S. J. Salveson and J. R. Dunn: Northwest \& Alaska Fish. Center Processed Report, 393-405 (1976).

10) E. W. Fager: Ecology, 38(4), 386-595 (1957).

11) E. W. Fager: in "The Sea" (ed. by M. N. Hill), Vol. 2, Interscience, London, 1963, pp. 415-437.

*1 K. Mito: Food relationships among benthic fish populations in the Bering Sea: on the Theragra chalcogramma fishing grounds in October and November of 1972, Master Thesis, Hokkaido Univ., Hakodate, $1974,135 \mathrm{p}$.

*2 M. J. Allen: Functional organization of demersal fish communities of the eastern Bering Sea, 1984 (unpubl.). 